\title{
The impact of UV-B radiation on antioxidant activity, essential oil composition and physiological factors of Pelargonium graveolens L'Hér.
}

\author{
Marjan AZARAFSHAN ${ }^{1}$, Maryam PEYVANDI ${ }^{1,2}$, Hossein ABBASPOUR ${ }^{1}$, Zahra NOORMOHAMMADI ${ }^{3}$, \\ Ahmad MAJD ${ }^{1}$
}

Received January 10, 2019; accepted April 05, 2019.

Delo je prispelo 10. januarja 2019, sprejeto 05. aprila 2019.

The impact of UV-B radiation on antioxidant activity, essential oil composition and physiological factors of Pelargonium graveolens L'Hér.

Abstract: Pelargonium graveolens L'Hér. is an important aromatic and medicinal plant, which is famous for its essential oils $\left(\mathrm{EO}_{\mathrm{s}}\right)$. The aim of this study was to evaluate the effects of UV-B on growth factors, essential oils components, antioxidant activity of essential oils and antioxidant enzymes activity, carbohydrate content, leaf pigments and total protein. Cuttings from potted plants were exposed to $0,0.12,0.26$, and $0.38 \mathrm{~W} \mathrm{~m}^{-2}$ of UV-B radiation. The antioxidant enzyme activity, carbohydrate content and protein and pigments contents were measured by spectrophotometric methods. The composition of $\mathrm{EO}_{\mathrm{S}}$ was analyzed by GC-MS. The antioxidant activity of the $\mathrm{EO}_{\mathrm{S}}$ was analyzed by free radical scavenging activity using the 2,2-diphenyl-1-picrylhydrazyl (DPPH). Results demonstrated that the leaves' fresh and dry mass, plant height, number of leaves, and the content of chlorophyll, protein and total carbohydrates were significantly $(P \leq 0.05)$ decreased, when plants were subjected to increased intensity of UV radiation. In contrast, the content of carotenoids and antioxidant enzymes activities increased. The chemical composition of $\mathrm{EO}_{\mathrm{S}}$ indicated that the main components in all treated plants were citronellol, geraniol, and citronellyl formate. The antioxidant activity of the essential oils increased with increasing UV-B radiation. The maximum and minimum IC50 values of essential oils were obtained in control plants and plants under $0.38 \mathrm{~W} \mathrm{~m}^{-2} \mathrm{UV}-\mathrm{B}$ radiation, respectively.

Key words: Pelargonium graveolens; UV-B radiation; essential oil; antioxidant activity; antioxidant enzymes.
Vpliv UV-B sevanja na antioksidacijsko aktivnost, sestavo eteričnih olj in fiziološke parametre roženkrauta (Pelargonium graveolens L'Hér.)

Izvleček: Roženkravt (Pelargonium graveolens L'Hér.) je med gojenimi pelargonijami pomembna aromatična in zdravilna rastlina zaradi vsebnosti eteričnih olj $\left(\mathrm{EO}_{\mathrm{s}}\right)$. Namen te raziskave je bil ovrednotiti učinke UV-B sevanja na njene rastne parametre, vsebnost eteričnih olj, antioksidacijsko aktivnost eteričnih olj in antioksidacijskih encimov, vsebnost ogljikovih hidratov, listnih pigmentov in celokupnih beljakovin. Potaknjenci iz v loncih vzgojenih rastlin so bili izpostavljeni $0 ; 0,12$; 0,26 , in $0,38 \mathrm{~W} \mathrm{~m}^{-2} \mathrm{UV}-\mathrm{B}$ sevanja. Aktivnost antioksidacijskih encimov, vsebnost ogljikovih hidratov, beljakovin in listnih barvil so bile izmerjene s spektrofotometričnimi metodami. Sestava eteričnih olj je bila analizirana z GC-MS metodo. Antioksidacijska aktivnost eteričnih olj je bila analizirana $\mathrm{z}$ aktivnostjo lovilcev prostih radikalov z uporabo 2, 2-difenil-1-pikrilhidrazila (DPPH). Rezultati so pokazali, da se je vrednost parametrov kot so sveža in suha masa listov, višina rastlin, število listov, vsebnost klorofila, beljakovin in celokupnih ogljikovih hidratov značilno $(P \leq 0,05)$ zmanjšala, če so bile rastline izpostavljene povečanemu UV sevanju. Nasprotno sta se vsebnost karotenoidov in aktivnost antioksidacijskih encimov povečali. Kemijska sestava eteričnih olj je pokazala, da so bile njihove glavne sestavine pri vseh obravnavanih rastlinah citronelol, geraniol in citronelil format. Antioksidacijska aktivnost eteričnih olj se je povečala $\mathrm{z}$ naraščanjem jakosti UV-B sevanja. Maksimalna in minimalna IC50 vrednost eteričnih olj sta bili dobljeni pri kontrolnih rastlinah, izpostavljenih UV-B sevanju 0,38 $\mathrm{W} \mathrm{m}^{-2}$.

Ključne besede: Pelargonium graveolens; UV-B sevanje; eterična olja; antioksidacijska aktivnost; antioksidacijski encimi

1 Islamic Azad University, Faculty of Biological Sciences, North Tehran Branch, Department of Biology, Tehran, Iran

2 Corresponding author, e-mail: m_peyvandi@iau-tnb.ac.ir

3 Islamic Azad University, Science and Research Branch, Department of Biology, Tehran, Iran 


\section{INTRODUCTION}

Pelargonium graveolens (L'Hér), belonging to the Geraniaceae family, is planted for its valuable oil, which is generally called geranium oil and is widely used in cosmetics, perfumery and food industry (Pandey \& Patra, 2015).The geranium oil has anti-bacterial and anti-fungal properties. It was been used in ancient medicine for the treatment of diabetes, allergies, asthma, and diarrhea, and now it is used to treat heart disease, hemorrhoids, infertility and even cancer (Boukhris et al., 2013; Fayed, 2009).

Ozone $\left(\mathrm{O}_{3}\right)$ is a unique air pollutant gas absorbing $\mathrm{UV}-\mathrm{B}$ radiation in the stratosphere (Inostroza-Blancheteau et al., 2016). Over the past few decades, the ozone layer has been destroyed by CFCs and other man-made pollutant gases. Therefore, more UV-B radiation reaches the surface of the earth (Rai et al., 2011).

High levels of UV-B radiation cause DNA damage, increased production of reactive oxygen species (ROS), reduced photosynthesis, damage to photosystem II, and reduced chlorophyll content and lipid peroxidation, which ultimately negatively affect the growth of plants, crop production and the natural state of plants in the ecosystem (Arora et al., 2002; Hollosy, 2002). Plants produce many UV-absorbing compounds such as flavonoids and carotenoids (Rai et al., 2011). On the other hand, the activity of some antioxidant enzymes such as catalase (CAT), superoxide dismutase (SOD), and peroxidase (POD), as scavengers for free oxygen radicals, increase to help plants resist oxidative stress under UV-B radiation (Hui et al., 2015). Among the various plant metabolites, the production of essential oils in medicinal plants and aromatic plants is of utmost importance (Cavar \& Maksimovic, 2012). The UV-B radiation has different effects on the essential oils; for example, the UV-B radiation increases the essential oils content in the peppermint, while the essential oils quality does not change. In contrast, the UV-B treatment has no effect on the quality and quantity of basil essential oils (Chang et al., 2009). Essential oils, as secondary metabolites, can replace synthetic antioxidants mainly due to the antioxidant behaviour of terpenes (Kamohara \& Naparatanawong, 2013).

To our knowledge, no studies are available on the effects of UV-B radiation on Pelargonium graveolens, as yet. Therefore the aim of the presented study was to investigate the effects of UV-B on growth factors, essential oils components, antioxidant activity of essential oils and antioxidant enzymes, carbohydrate content, leaf pigments and total protein in $P$. graveolens.

\section{MATERIALS AND METHODS}

\subsection{PLANT MATERIALS AND GROWTH CONDI- TIONS}

The $P$. graveolens stock plant from a greenhouse belonging to the National Botanical Garden of Iran was used. The cuttings were transfer to the plastic pots (12 $\mathrm{x} 10 \mathrm{~cm}$ ) filled with a mixture of soil / sand (1:1) and kept in the greenhouse. The greenhouse conditions were 16 hours light: 8 hours dark photoperiod at a temperature of $22 / 7^{\circ} \mathrm{C}$ (day/night), and a relative humidity of $56 \%$. The photosynthetic active radiation was 194 $\mu \mathrm{mol} \mathrm{m}{ }^{-2} \mathrm{~s}^{-1}$, provided by two $40 \mathrm{~W}$ white light lamps (Parskazar, Iran). The plants were grown for two months or until five-leaf stage prior investigation.

\subsection{UV-B TREATMENT}

The experiment had a randomized design with three replications for each treatment and twelve plants for each replicate. The plants were treated by UV-B radiation $(0$, $0.12,0.26$, and $0.38 \mathrm{~W} \mathrm{~m}^{-2}$ ) for 10 minutes/day during seven days. The UV-B radiation source was artificially supplied with the Sankyo Denki lamps (G15T8E /Japan) at a distance of $70 \mathrm{~cm}$ above the plants. The plants were harvested for analysis after two weeks. Growth factors including shoot fresh and dry mass, stem length, and the numbers of leaves were measured.

\subsection{TOTAL CARBOHYDRATE ASSAY}

Carbohydrates were measured according to the Kochert (1978) method. Approximately, $0.1 \mathrm{~g}$ of leaf dry matter was homogenized in $10 \mathrm{ml}$ ethanol $70 \%$.

The samples were kept at $4{ }^{\circ} \mathrm{C}$ for one week. Then, $1 \mathrm{ml}$ of phenol $5 \%$ and $5 \mathrm{ml}$ of pure sulfuric acid were added to $1 \mathrm{ml}$ of each sample, and the absorbance of the solutions was measured at $485 \mathrm{~nm}$ by spectrophotometer.

\subsection{PIGMENTS ASSAY}

Approximately $0.1 \mathrm{~g}$ of the fresh leaves of each sample was homogenized with $10 \mathrm{ml}$ acetone ( $80 \%$ ), according to the Lichtenthaler (1987) method. The absorbance was scanned spectrophotometrically $(400-700 \mathrm{~nm})$ to calculate the content of chlorophyll a and b, total chlorophyll, and carotenoids. 


\subsection{PROTEIN CONTENT AND ANTIOXIDANT ENZYMES ACTIVITY ASSAY}

Approximately $0.5 \mathrm{~g}$ of the fresh leaves of each sample was homogenized with $5 \mathrm{ml}$ Tris-glycine buffer. The extract was used to determine the protein content by Bradford's (1976) method, CAT activity by Pereira et al. (2002), SOD activity by Giannopolitie and Ries (1997), and POD activity by Koroi (1989) protocols.

\subsection{ESSENTIAL OIL EXTRACTION}

Approximately, $50 \mathrm{~g}$ of the leaf dry matter of $P$. graveolens was used to extract the essential oil by hydrodistillation method in a Clevenger type apparatus for 3 hours at $60{ }^{\circ} \mathrm{C}$. Then, the essential oil was dried over $\mathrm{Na}_{2} \mathrm{SO}_{4}$. The samples were weighed by a digital scale and stored in closed vials at $4{ }^{\circ} \mathrm{C}$ for further analysis.

\subsection{GC ANALYSIS}

The chemical compositions of oil samples were analysed on a Thermo-UFM (Ultra Fast Model, Italy) gas chromatograph equipped with a flame ionization detector (FID) and a Ph-5 capillary column $(10 \mathrm{~m} \times 0.1 \mathrm{~mm}$ ID, $0.25 \mu \mathrm{m}$ film thickness).

The column heating program was as follows: the initial temperature was set to $60^{\circ} \mathrm{C}$ for $3 \mathrm{~min}$, and then increased at a rate of $40{ }^{\circ} \mathrm{C} \mathrm{min}-1$ to $246{ }^{\circ} \mathrm{C}$, and hold for $8.63 \mathrm{~min}$.

The carrier gas was helium with a flow rate of $0.5 \mathrm{ml} \mathrm{min}{ }^{-1}$. The injection port and detector temperatures were both $280^{\circ} \mathrm{C}$.

\subsection{GC-MS ANALYSIS}

GC-MS analyses were carried out on a Varian 3400 (Saturn II, USA) GC/MS system equipped with a DB-5 fused silica column $(30 \mathrm{~m}, 0.25 \mathrm{~mm}$ ID, and $0.25 \mu \mathrm{m}$ film- thickness). The carrier gas was helium with a linear velocity of $31.5 \mathrm{~cm} \mathrm{~s}^{-1}$, split ratiol/60. The ionization energy was $70 \mathrm{eV}$ and the scan time was $1 \mathrm{~s}$. The oven temperature was $40-240{ }^{\circ} \mathrm{C}$ at a rate of $3{ }^{\circ} \mathrm{C} \mathrm{min}^{-1}$, the injector temperature was $250^{\circ} \mathrm{C}$, and the transfer line temperature was $260^{\circ} \mathrm{C}$. Identification of essential oil components was carried out using the mass spectra of compounds and the data from NIST GS-MS library.

\subsection{ESSENTIAL OIL ANTIOXIDANT ACTIVITY}

The DPPH assay was determined according to Akowuah et al. (2005) method. 2, 2-diphenyl-1-picrylhydrazyl (DPPH, $0.004 \%$ ) was prepared freshly before analysis and butylated hydroxytoluene (BHT) was used as positive control. First, the essential oil was diluted with methanol, and then five volumes $(50-250 \mu \mathrm{l})$ of the diluted essential oil reached $3 \mathrm{ml}$. Then, $1 \mathrm{ml}$ of DPPH was added to the samples and incubated for $30 \mathrm{~min}$. The absorbance was read at $517 \mathrm{~nm}$ and the inhibition percentage was calculated with I $\%=((\mathrm{Ab}-\mathrm{As}) / \mathrm{Ab}) \mathrm{X} 100$ (where $\mathrm{Ab}$ is the absorbance of negative control reaction and As is the absorbance of samples). Percentage of inhibition after 30 min was plotted against concentration, and the equation for the line was used to obtain the IC50 value.

\subsection{STATISTICAL ANALYSIS}

All statistical analyses were done in the SPSS software; version 16 (IBM Company). The mean values of three replications and the standard error of means were calculated for the biochemistry parameters and growth factors. One-way ANOVA was used to determine the significance of the differences between treatments using the Duncan's multiple range test $(P \leq 0.05)$.

\section{RESULTS AND DISCUSSION}

\subsection{GROWTH FACTORS}

The stem length significantly decreased $(P \leq 0.05)$ in all UV treated plants. The lowest stem lengths were recorded in $0.38 \mathrm{~W} \mathrm{~m}^{-2}$ treatment, whereas the highest lengths were determined in control treatment (Table1). The mean values of leaf fresh and dry mass decreased significantly with increasing UV-B radiation. The highest leaf number was obtained in the control treatment; however, there were no significant differences between the mean values of leaf number between different UVtreatments (Table1).

Our findings showed that UV-B radiation significantly decreased the plant length, leaf number, and leaf dry and fresh mass. Teramura (1983) reported that the increased production of phytohormones under UV, such as auxin and ethylene, affected the plant growth. It is well known that ROS production increased lipid peroxidation and ethylene. On the other hand it was reported that the auxin (IAA) content decreased under UV condition (Krizek et al., 1998; Teramura, 1983).The reduced plant 
Table 1: Stem length, fresh and dry mass of leaves and leave number under different UV-B radiation

\begin{tabular}{lllll}
\hline UV-B $\left(\mathrm{Wm}^{-2}\right)$ & Stem length $(\mathrm{cm})$ & Leaves FM $(\mathrm{g})$ & Leaves DM $(\mathrm{g})$ & Leaves no. \\
\hline 0 & $9.833 \pm 0.48(\mathrm{a})$ & $2.733 \pm 0.10(\mathrm{a})$ & $0.192 \pm 0.01(\mathrm{a})$ & $7.500 \pm 0.26(\mathrm{a})$ \\
0.12 & $7.358 \pm 0.39(\mathrm{~b})$ & $2.304 \pm 0.23(\mathrm{a}, \mathrm{b})$ & $0.193 \pm 0.01(\mathrm{a})$ & $5.833 \pm 0.11(\mathrm{~b})$ \\
0.26 & $5.866 \pm 0.37(\mathrm{c})$ & $1.957 \pm 0.26(\mathrm{~b})$ & $0.130 \pm 0.023(\mathrm{~b})$ & $5.750 \pm 0.13(\mathrm{~b})$ \\
0.38 & $4.191 \pm 0.33(\mathrm{~d})$ & $1.274 \pm 0.13(\mathrm{c})$ & $0.081 \pm 0.007(\mathrm{c})$ & $5.333 \pm 0.14(\mathrm{~b})$ \\
\hline
\end{tabular}

Data are means of twelve replicates with standard errors (Mean \pm SE); different letters indicate significant differences between treatments $(p \leq 0.05)$.

length and increased growth diameter are caused by high ethylene content (Krizek et al., 1998). The increased activity of some peroxidase, which acts as auxin oxidases, can reduce the flexibility of cells under UV radiation and affect all growth factors such as mass, length, and leaf number (Hollosy, 2002). Hollosy (2002) found out that reduced cell membrane flexibility caused the reduced growth length. Kakani et al. (2003) and Zukgolaszewska et al. (2003) reported that UV-B radiation decreased the plant length. Liu et al. (2013) studied the effects of UV-B radiation on the growth characteristics of three soybean cultivars. Similar to our study, they stated that the increased UV-B radiation caused decreased plant mass and length. Valkama et al. (2003) reported that the UV-B radiation caused a reduction of leaf number in strawberry and barley. In Vigna mungo (L.) Hepper, the UV-B radiation reduced the leaf number and leaf fresh and dry mass (Rajendiran et al., 2015).

\subsection{PHOTOSYNTHETIC PIGMENTS}

With increasing UV-B radiation, different effects on photosynthetic pigments were observed. By increasing UV radiation intensity, chlorophyll a, b and total chlorophyll contents decreased. In contrast, the carotenoids content significantly increased when plants were treated with higher levels of UV-B $\left(0.26\right.$ and $\left.0.38 \mathrm{Wm}^{-2}\right)$ (Table 2).

In this study, the content of chlorophyll $\mathrm{a}$ and $\mathrm{b}$ and total chlorophyll in all treatments decreased in compari- son with the control plants. Rai et al. (2011) treated the Artemisia annua L. with UV-B and UV-C. They reported that UV-B radiation decreased the content of chlorophyll a, b and total chlorophyll significantly. Hui et al. (2015) analyzed the effects of UV-B radiation on two key spices of soil crusts in China and reported that UV-B stress decreased the chlorophyll content. Both of these reports are in agreement with our study. The UV-B radiation decreased the chlorophyll content by destroying the structure of chloroplasts and decreasing the synthesis of new chlorophylls. The higher ethylene production rate under UV-B radiation can cause chlorophyll degradation (Krizek et al., 1998;Teramura, 1983). Results showed that the content of carotenoids increased with higher UV-B radiation intensity. Carotenoids are ROS scavengers and very active in protecting the plant against photo-oxidation. They can protect chlorophylls against UV-B radiation by dispersing extra stimulating energy (Hui et al., 2015; Rai et al., 2011).

\subsection{TOTAL CARBOHYDRATES}

The content of carbohydrates decreased with increasing UV-B radiation. The highest and lowest carbohydrate content was observed in the control and $0.38 \mathrm{~W} \mathrm{~m}^{-2}$ treatments respectively (Table 2).

Alteration in carbohydrates content is usual phenomenon in abiotic stresses. Reduction in soluble sugars was reported in Eucalyptus and Acacia (Liu et al.,

Table 2: Chl-a, Chl-b, Chl a+b, carotenoids and total carbohydrate under different UV-B radiation

\begin{tabular}{llllll}
\hline UV-B $\left(\mathrm{W} \mathrm{m}^{-2}\right)$ & Chl-a $\left(\mathrm{mg} \mathrm{g}^{-1} \mathrm{fm}\right)$ & Chl-b $\left(\mathrm{mg} \mathrm{g}^{-1} \mathrm{fm}\right)$ & Carotenoids $\left(\mathrm{mg} \mathrm{g}^{-1} \mathrm{fm}\right)$ & Chl.a $+\mathrm{b}\left(\mathrm{mg} \mathrm{g}^{-1} \mathrm{fm}\right)$ & $\begin{array}{l}\text { Total carbohy- } \\
\text { drate }\left(\mathrm{mg} \mathrm{g}^{-1} \mathrm{dm}\right)\end{array}$ \\
\hline 0 & $8.415 \pm 0.10(\mathrm{a})$ & $3.139 \pm 0.04(\mathrm{a})$ & $3.950 \pm 0.01(\mathrm{c})$ & $11.554 \pm 0.11(\mathrm{a})$ & $6.539 \pm 0.25(\mathrm{a})$ \\
0.12 & $8.177 \pm 0.03(\mathrm{a})$ & $2.972 \pm 0.04(\mathrm{a}, \mathrm{b})$ & $3.964 \pm 0.04(\mathrm{c}, \mathrm{b})$ & $11.090 \pm 0.06(\mathrm{~b})$ & $5.816 \pm 0.11(\mathrm{a}, \mathrm{b})$ \\
0.26 & $7.714 \pm 0.12(\mathrm{~b})$ & $2.955 \pm 0.08(\mathrm{a} . \mathrm{b})$ & $3.977 \pm 0.06(\mathrm{~b}, \mathrm{a})$ & $10.669 \pm 0.04(\mathrm{~b})$ & $5.298 \pm 0.38(\mathrm{~b})$ \\
0.38 & $7.382 \pm 0.14(\mathrm{~b})$ & $2.703 \pm 0.18(\mathrm{~b})$ & $3.982 \pm 0.08(\mathrm{a})$ & $10.085 \pm 0.25(\mathrm{c})$ & $4.007 \pm 0.18(\mathrm{c})$ \\
\hline
\end{tabular}

Data are means of three replicates with standard errors (Mean \pm SE). Different letters indicate significant differences between treatments $(p \leq 0.05)$. 
2005), corn (An et al., 2000) and linen (Tossi et al., 2009) in response to UV radiation.

UV-B radiation has diverse environmental roles in plants ranging from regulatory to damaging (Jansen \& Bornman, 2012). The changes in carbohydrates amount under the abiotic stresses like UV-B may be due to damaging the structure of chloroplast and blocking of chloroplast electron transport, which provides ATP and NADPH for the production of carbohydrates. The decreased chlorophyll contents can be directly correlated with lower level of carbohydrates contents (Bano et al., 2017). Earlier, it has been reported that oxidative stress induced by UV-B radiation can destroy macromolecules such as proteins, carbohydrates, and nucleic acids (Salma et al., 2011). However, Singh et al. (2015) suggested that there is proper balance between different metabolites under elevated UV-B. The observed degradation in concentration of sugars during UV radiation stress confirms also the fact that sugars play a vital role in signaling and providing energy source for the synthesis of secondary metabolites.

\subsection{PROTEIN CONTENT AND ANTIOXIDANT ENZYMES ACTIVITY}

Increasing UV-B radiation increases the activity of antioxidant enzymes. In all UV treatments, the protein content significantly decreased $(P \leq 0.05)$ compared to the control (Table 3 ).

The proteins with aromatic amino acids are known to be more susceptible to by UV-B stress (Kovacs \& Kreseszfes, 2002).

In addition, the synthesis of proteins is disrupted under UV-B radiation. D1 and D2 proteins, RUBISCO, and ATPase complex are some important proteins that are affected and destroyed by UV-B (An et al., 2000). Our results showed that protein content decreased with increasing UV radiation intensity. The UV-B radiation not only causes structural modification and damages to amino acids, but also can disable proteins (Casati \& Wal- bot, 2004). Takshak and Agrawal (2015) reported that in Plectranthus barbatusAndrews under UV-B stress, the protein content of leaves and roots decreased in all growth stages. The increased activity of SOD, POD and $\mathrm{CAT}$, as the key enzymes for scavenging of free oxygen radicals, was observed in our study. The SOD is responsible for dismutation of anion superoxide and reducing the risk of radical hydroxyl production under UV-B radiation (Arora et al., 2002). Meiling et al. (2012) in a study on flavonoid signal pathway under UV-B radiation in Caryopteris mongholica Bunge reported that SOD activity was increased under UV-B exposure. In addition, an increase in POD activity may occur in detoxification of $\mathrm{H}_{2} \mathrm{O}_{2}$ (Arora et al., 2002). Yannarelli et al. (2006) reported an increase in POD in sunflower cotyledons under UV-B radiation. Xu et al. (2008) studied the soya bean responses under UV-B radiation and reported that CAT activity increased under UV-B radiation.

\subsection{ESSENTIAL OILS QUALITY AND QUANTITY}

The essential oils content were increased with increasing UV-B radiation. The highest $(0.70 \mathrm{w} / \mathrm{w})$ and lowest $(0.54 \mathrm{w} / \mathrm{w})$ essential oils contents were obtained in the $0.38 \mathrm{~W} \mathrm{~m}^{-2}$ and in the control treatments, respectively. The amount of essential oils of 0.12 and $0.28 \mathrm{~W} \mathrm{~m}^{-2}$ treated plants was the same $(0.68 \mathrm{w} / \mathrm{w})$. The GC/MS results showed (Figure1) that some of the important essential oils components such as citronellol and geraniol were increased along with increasing UV-B radiation. However, some components like $\gamma$-eudesmol, citronellyl butyrate, citronellyl formate, bornyl acetate, and germacrene D were decreased (Table 4).

All studied samples were rich in citronellol and geraniol as the main components.Therefore, the essential oils of $P$. graveolens are known as the citronellol and geraniol chemo type. The essential oils contain oxygenated monoterpens or alcohol monoterpens such as citronellol and geraniol, monoterpens such as isomenthone, and sesqueiterpens such as caryophyllen and germacrene D.

Table 3: Total protein, catalase (CAT), peroxidase (POD) and superoxide dismutase (SOD) activity under different UV-B radiationn

\begin{tabular}{lllll}
\hline UV-B & Protein & CAT & POD & SOD \\
$\left(\mathrm{W} \mathrm{m}^{-2}\right)$ & $\left(\mathrm{mg} \mathrm{g}^{-1} \mathrm{fm}\right)$ & $\left(\Delta\right.$ OD.min $\mathrm{mg}^{-1}$ protein $)$ & $\left(\Delta\right.$ OD.min $\mathrm{mg}^{-1}$ protein $)$ & (unitmg $\left.{ }^{-1} \mathrm{protein}\right)$ \\
\hline 0 & $3.337 \pm 0.20(\mathrm{a})$ & $0.387 \pm 0.11(\mathrm{C})$ & $1.165 \pm 0.17(\mathrm{c})$ & $0.282 \pm 0.03(\mathrm{c})$ \\
0.12 & $2.996 \pm 0.056(\mathrm{a}, \mathrm{b})$ & $2.477 \pm 0.51(\mathrm{~b})$ & $3.894 \pm 0.56(\mathrm{~b})$ & $0.478 \pm 0.02(\mathrm{~b})$ \\
0.26 & $2.892 \pm 0.082(\mathrm{~b})$ & $2.696 \pm 0.46(\mathrm{~b})$ & $4.608 \pm 1.15(\mathrm{~b})$ & $0.546 \pm 0.03(\mathrm{~b})$ \\
0.38 & $2.726 \pm 0.90(\mathrm{~b})$ & $3.838 \pm 0.48(\mathrm{a})$ & $8.558 \pm 1.22(\mathrm{a})$ & $0.760 \pm 0.024(\mathrm{a})$ \\
\hline
\end{tabular}

Data are means of three replicates with standard errors (Mean \pm SE). Different letters indicate significant differences between treatments $(p \leq 0.05)$. 
In this study, the percentage of volatile oil (w/w) was increased with increasing UV-B radiation. In most cases, the production of secondary metabolites was increased under stress condition (Matos Nunes et al., 2014). Plants produce secondary metabolites in leaves and accumulate it in epidermal layer to absorb UV-B radiation (Kakani et el., 2003). Johnson et al. (1999) reported that UV-B increased the quality and quantity of volatile oil in basil plants. The essential oils composition of $P$. graveolens under UV radiation has not been studied, as yet. Therefore, we compared our findings on some of the important compounds of $P$. graveolens with similar compounds in other plants under UV stress. Similar to our findings, bornyl acetate is reported to be reduced in Artemisia annua L. under UV-B radiation (Pandey \& Pandey-
Rai, 2014). Germacrene B was reduced in O. basilicum (Chang et al., 2009) and A. annua (Pandey \& PandeyRai, 2014). Citronellol and geraniol increased in grapes treated with UV-treatment (Song et al., 2015). Manukyan (2013) reported that UV-B radiation could increase the bioactive compounds such as geraniol and citronellol in medical plants.

\subsection{ANTIOXIDANT ACTIVITY}

The IC50 was significantly $(P \leq 0.05)$ decreased with increasing UV-B radiation. The results showed that the antioxidant activity of the essential oils of treated plants

Table 4: Percentage of essential oils components under different UV-B radiation

\begin{tabular}{|c|c|c|c|c|c|c|}
\hline RT & Name & & Control \% & $\mathrm{T} 1 \%$ & T2 \% & T3\% \\
\hline 2.61 & cis-rose oxide & $\mathrm{C}_{10} \mathrm{H}_{18} \mathrm{O}$ & 1.1864 & 1.4911 & 1.0053 & 1.1715 \\
\hline 2.67 & trans-rose oxide & $\mathrm{C}_{10} \mathrm{H}_{18} \mathrm{O}$ & 0.78 & 1.0277 & 1.0796 & 1.7525 \\
\hline 2.97 & isomenthone & $\mathrm{C}_{10} \mathrm{H}_{18} \mathrm{O}$ & 2.2638 & 2.1742 & 2.1511 & 3.0934 \\
\hline 3.13 & citronellol & $\mathrm{C}_{10} \mathrm{H}_{20} \mathrm{O}$ & 48.1634 & 49.3096 & 48.4592 & 49.8152 \\
\hline 3.22 & geraniol & $\mathrm{C}_{10} \mathrm{H}_{18} \mathrm{O}$ & 12.2863 & 18.4966 & 16.5241 & 14.3379 \\
\hline 3.27 & citronellyl formate & $\mathrm{C}_{11} \mathrm{H}_{20} \mathrm{O}_{2}$ & 10.978 & 8.0398 & 7.5222 & 8.6425 \\
\hline 3.30 & verbenyl acetate & $\mathrm{C}_{12} \mathrm{H}_{18} \mathrm{O}_{2}$ & 0.307 & 0.353 & 0.3559 & 0.3371 \\
\hline 3.37 & bornyl acetate & $\mathrm{C}_{12} \mathrm{H}_{20} \mathrm{O}_{2}$ & 2.3254 & 1.724 & 1.7357 & 1.7116 \\
\hline 3.52 & citronellyl acetate & $\mathrm{C}_{12} \mathrm{H}_{22} \mathrm{O}_{2}$ & 0.3168 & 0.2874 & 0.2812 & 0.4184 \\
\hline 3.73 & a-copaene & $\mathrm{C}_{15} \mathrm{H}_{24}$ & 0.5142 & 0.4741 & 0.5638 & 0.6215 \\
\hline 3.77 & $\beta$-bourbonene & $\mathrm{C}_{15} \mathrm{H}_{24}$ & 0.3974 & 0.3945 & 0.5658 & 0.5604 \\
\hline 3.83 & E-caryophyllene & $\mathrm{C}_{15} \mathrm{H}_{24}$ & 0.7627 & 0.5529 & 0.5529 & 0.7485 \\
\hline 3.91 & citronellyl propionate & $\mathrm{C}_{13} \mathrm{H}_{24} \mathrm{O}_{2}$ & 0.7384 & 0.6008 & 0.8496 & 0.8111 \\
\hline 3.93 & germacrene D & $\mathrm{C}_{15} \mathrm{H}_{24}$ & 0.9667 & 0.6233 & 0.5749 & 0.5312 \\
\hline 4.06 & $\beta$-curcumene & $\mathrm{C}_{15} \mathrm{H}_{24}$ & 0.5642 & 0.6233 & 0.6315 & 0.5405 \\
\hline 4.12 & citronellyl butanoate & $\mathrm{C}_{14} \mathrm{H}_{26} \mathrm{O}_{2}$ & 4.1837 & 2.2097 & 3.2676 & 2.6706 \\
\hline 4.16 & -cadinene $\gamma$ & $\mathrm{C}_{15} \mathrm{H}_{28}$ & 0.4524 & 0.3765 & 0.5423 & 0.3231 \\
\hline 4.19 & elemol & $\mathrm{C}_{15} \mathrm{H}_{26} \mathrm{O}$ & 0.7149 & 0.5786 & 0.7657 & 0.8285 \\
\hline 4.21 & germacrene B & $\mathrm{C}_{15} \mathrm{H}_{24}$ & 0.9725 & 0.5634 & 0.7623 & 0.7858 \\
\hline 4.23 & $\beta$-calacorene & $\mathrm{C}_{15} \mathrm{H}_{20}$ & 0.3076 & 0.2632 & 0.3018 & 0.3869 \\
\hline 4.41 & -eudesmol $\gamma$ & $\mathrm{C}_{15} \mathrm{H}_{26} \mathrm{O}$ & 2.3083 & 2.0929 & 2.1044 & 2.1793 \\
\hline 4.45 & $\beta$-eudesmol & $\mathrm{C}_{15} \mathrm{H}_{26} \mathrm{O}$ & 0.4744 & 0.9735 & 0.9087 & 0.7709 \\
\hline 4.48 & $\beta$-bisabolol & $\mathrm{C}_{15} \mathrm{H}_{26} \mathrm{O}$ & 0.5645 & 0.5617 & 0.6598 & 1.0399 \\
\hline 4.55 & $\beta$-sinensal & $\mathrm{C}_{15} \mathrm{H}_{22} \mathrm{O}$ & 1.064 & 0.9986 & 1.2491 & 0.956 \\
\hline 4.58 & (E,E)farnesol & $\mathrm{C}_{15} \mathrm{H}_{26} \mathrm{O}$ & 0.5824 & 0.395 & 0.6048 & 0.4153 \\
\hline 4.66 & khusimol & $\mathrm{C}_{15} \mathrm{H}_{24} \mathrm{O}$ & 3.4842 & 3.2469 & 4.2292 & 2.4259 \\
\hline 4.68 & -sinensala & $\mathrm{C}_{15} \mathrm{H}_{22} \mathrm{O}$ & 0.5301 & 0.2978 & 0.6175 & 0.4147 \\
\hline
\end{tabular}

Control: without UV-B, T1: $0.12 \mathrm{~W} \mathrm{~m}^{-2}$, T2: $0.26 \mathrm{~W} \mathrm{~m}^{-2}$ and T3: $0.38 \mathrm{~W} \mathrm{~m}^{-2}$ ). RT: Retention time. 


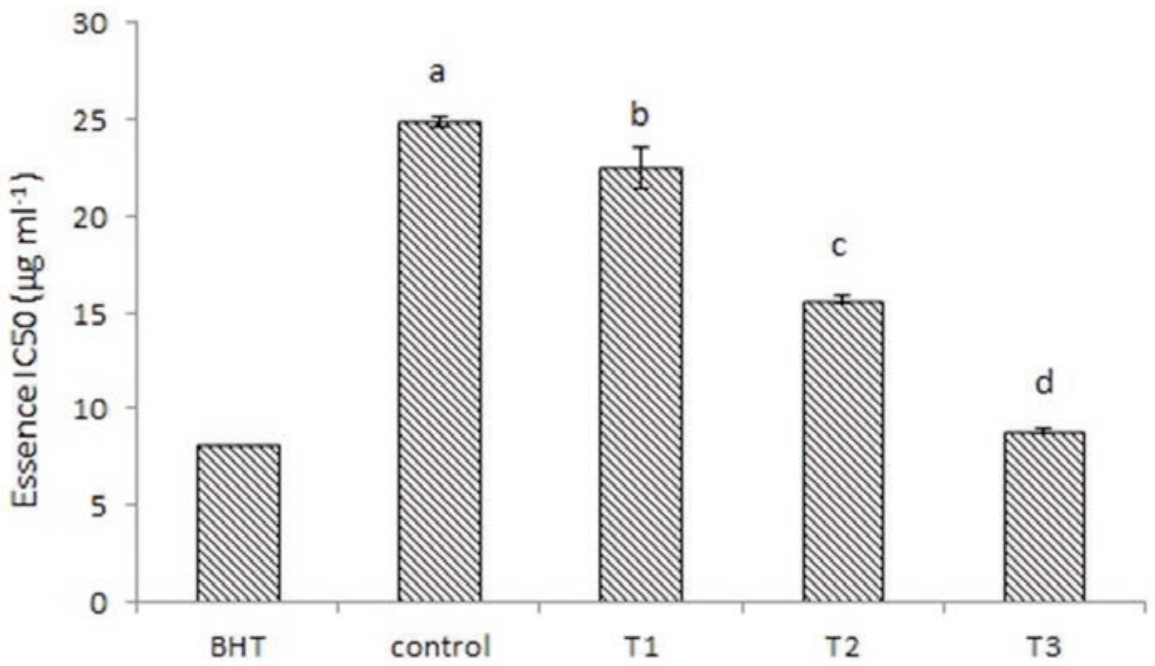

Figure 1: IC50 of essential oils under different UV-B radiation (control: without UV-B, T1: $0.12 \mathrm{~W} \mathrm{~m}^{-2}, \mathrm{~T} 2: 0.26 \mathrm{~W} \mathrm{~m}^{-2}$ and T3: $0.38 \mathrm{~W} \mathrm{~m}^{-2}$ ). Bars are standard errors (Mean $\pm \mathrm{SE}$ ) . Different letters indicate significant differences between treatments $(P \leq 0.05)$.

with the highest UV-B radiation was approximately equal to the commercial antioxidant (BHT) (Figure1).

Results indicated that the antioxidant activity of the essential oils increased (IC50 decreased) with elevating UV-B radiation. This activity can be related to the main essential components such as geraniol and citronellol, which are increased in the plant under UV-B 0.26 and $0.38 \mathrm{~W} \mathrm{~m}^{-2}$ treatments. Geraniol and citronellol are known as antioxidant compounds. It was previously reported that the ability of $P$. graveolens essential oils in $\mathrm{DPPH}$ radical reduction can be related to the high content of these two alcoholic monoterpenes or allylic alcohols (Boukhris et al., 2013; Cavar \& Maksimovic, 2012).

\section{CONCLUSION}

In conclusion, it seems that the use of UV-B radiation can improve the essential oil quality and quantity of the studied plant especially at a low intensity $(0.1 \mathrm{~W}$ $\mathrm{m}^{-2}$ ) and also increase the antioxidant activity of the essential oil in higher intensities $\left(0.26,0.38 \mathrm{~W} / \mathrm{m}^{-2}\right)$.In addition, high UV intensities show destructive effects on the growth parameters .

\section{REFERENCES}

Akowuah, G. A., Ismail, Z., Norhayati, I., Dikun, A. (2005). The effects of different extraction solvent of varying polarities on polyphenols of Orthosiphon stamineus and evaluation of the free radical scavenging activity. Food chem, 93, 311-317. https://doi.org/10.1016/j.foodchem.2004.09.028

An, L., Feng, H., Tang, X ., Wang, X. (2000). Changes of micro- somal membrane properties in spring wheat leaves (Triticum aestivum L.) exposed to enhanced ultraviolet-B radiation. Journal of Photochemistry and Photobiology Biology, 57, 60-65. https://doi.org/10.1016/S1011-1344(00)00077-4

Arora, A., Sairam, R. K., Srivastava, G. C. (2002). Oxidative stress and antioxidative system in plants. Current science, 82(10), 1227-1238.

Bano, C., Amist, N., Aina, S., Singh, N. B. (2017). UV-B radiation escalate allelopathic effect of benzoic acid on Solanum lycopersicum L. Scientia Horticulturae, 220, 199-205. https://doi.org/10.1016/j.scienta.2017.03.052

Boukhris, M., Simmonds, M. S. J., Sayadi, S., Bouaziz, M. (2013). Chemical composition and biological activities of polar extracts and essential oil of rose-scented geranium, Pelargonium graveolens. Phytotherapy research, 27(8), 12061213. https://doi.org/10.1002/ptr.4853

Bradford, M. (1976). A rapid and sensitive method for the quantitation of microgram quantities of protein utilizing the principle of protein-dye binding. Analytical Biochemistry, 72, 248-254. https://doi.org/10.1016/0003-2697(76)905273

Casati, P., \& Walbot, V. (2004). Crosslink of ribosomal proteins to RNA in maize ribosomes by UV-B radiation and its effects on translation. Plant physiology, 136, 3319-3332. https://doi.org/10.1104/pp.104.047043

Ćavar, S., \& Maksimović, M. (2012). Antioxidant activity of essential oil and aqueous extract of Pelargonium graveolens L' Her. Food control, 23, 263-267. https://doi.org/10.1016/j. foodcont.2011.07.031

Chang, X., Alderson, P. G., Wright, C. J. (2009). Enhanced UV-B radiation alters basil (Ocimum basilicum L.) growth and stimulates the synthesis of volatile oils. Journal of Agriculture and Forestry, 1 (2), 027-031.

Fayed, S. A. (2009). Antioxidant and Anticancer Activities of Citrus reticulate (Petitgrain Mandarin) and Pelargonium graveolens (Graniacea) Essential oils. Journal of Agriculture and Biological Science, 5 (5), 740-747. 
Giannopolitis, C. N., \& Ries, S. K. (1997). Superoxide dismutase. I. occurrence in higher plants. Plant Physiology, 59, 309-314. https://doi.org/10.1104/pp.59.2.309

Hollosy, F. (2002). Effects of Ultraviolet Radiation on Plant Cells. Micron, 33, 179-197. https://doi.org/10.1016/S09684328(01)00011-7

Hui, R., Li, X., Zhao, R., Liu, L., Gao, Y., Wei, Y. (2015). UV-B radiation suppresses chlorophyll fluorescence, photosynthetic pigment and antioxidant systems of two key species in soil crusts from the Tengger Desert, China. Journal of Arid Environments, 113, 6-15. https://doi.org/10.1016/j. jaridenv.2014.08.007

Inostroza-Blancheteau, C., Acevedo, P., Loyola, R., Arce-Johnson, P., Alberdi, M., Reyes-Diaz, M. (2016). Short -term UV-B radiation affects photosynthetic performance and antioxidant gene expression in high bush blueberry leaves. Plant physiology and biochemistry, 107, 301-309. https://doi. org/10.1016/j.plaphy.2016.06.019

Jansen, M. A. K., \& Bornman, J. F. (2012). UV-B radiation: from generic stressor to specific regulator. Physiologia Plantarum, 145, 501-504. https://doi.org/10.1111/j.13993054.2012.01656.x

Johnson, C. B., Kirby, J., Naxakis, G., Pearson, S. (1999). Substantial UV-B mediated induction of essential oils in sweet basil (Ocimum basilicum L.). Phytochem, 51, 507-510. https://doi.org/10.1016/S0031-9422(98)00767-5

Kakani, V. G., Reddy, K. R., Zhao, D., Mohammed, A. R. (2003). Effects of Ultraviolet-B Radiation on Cotton (Gossypium hirsutum L.) Morphology and Anatomy. Journal of Botany, 91, 817-826. https://doi.org/10.1093/aob/mcg086

Kamohara, S., \& Noparatanawong, S. (2013). A Coleus Forskohlii extract improves body composition in healthy volunteers: an open-label trial. Personalized Medicine Universe, 2, 25-27. https://doi.org/10.1016/j.pmu.2013.04.003

Kochert, G. (1978). Carbohydrate determination by phenolsulfuric acid method. In Hellebust JA, Craigie JS (Eds), Handbook of phycological methods. Physiological and biochemical methods (pp. 95-97). Cambridge, Cambridge University Press.

Koroi, S. A. (1989). Gel electrophoresis tissue and spectrophotometrscho unter uchungen zomeinfiuss der temperature auf struktur der amylase and peroxidase isoenzyme. Physiology Review, 20, 15-23.

Kovacs, E., \& Kreseszfes, A. (2002). Effect of gamma and UVB/C radiation on plant cells. Micron, 33, 199-210. https://doi.org/10.1016/S0968-4328(01)00012-9

Krizek, D. T., Brita, S. J., Miewcki, R. M. (1998). Inhibitory effects of ambient level of solar UV-A and UV-B on growth of cv. New Red Fire lettuce. Journal of Physiology Plant, 103 (143), 1-7. https://doi.org/10.1034/j.1399-3054.1998.1030101.x

Lichtenthaler, H. (1987). Chlorophylls and carotenoids: Pigments of photosynthetic biomembranes. Methods in Enzymology, 148, 350-382. https://doi.org/10.1016/00766879(87)48036-1

Liu, B., Liu, X., Li, Y., Herbert, S. J. (2013). Effects of enhanced UV-B radiation on seed growth characteristics and yield components in soybean. Field crops research, 154, 158-163. https://doi.org/10.1016/j.fcr.2013.08.006

Liu, L. X., Xu, S. M., Woo, K. C. (2005). Solar UV-B radiation on growth, photosynthesis and xanthophyll cycle in tropical acacias and eucalyptus. Environmental and Experimental Botany, 54, 121-130. https://doi.org/10.1016/j.envexpbot.2004.06.006

Manukyan, A. (2013). Effects of PAR and UV-B radiation on herbal yield, bioactive compounds and their antioxidant capacity of some medicinal plants under controlled environmental conditions. Photochemistry and Photobiology, 89, 406-414. https://doi.org/10.1111/j.1751-1097.2012.01242.x

Matos Nunes, J., Bertodo, L. O. O., Rosa, L. M. G., Von Poser, G. L., Rech, S. B. (20014). Stress induction of valuable secondary metabolites in Hypericum polyanthemum acclimatized plants. South African Journal of Botany, 94, 182-189. https:// doi.org/10.1016/j.sajb.2014.06.014

Meiling, L., Shenghui, Bo. Z., Yubin, L. (2012). Responses of the flavonoid pathway to UV-B radiation stress and the correlation with the lipid antioxidant characteristics in the desert plant Caryopteris Mongolia. Acta Ecologica Sinica, 32, 150 155. https://doi.org/10.1016/j.chnaes.2012.04.004

Pandey, N., \& Pandey-Rai, S. (2014). Modulations of physiological responses and possible involvement of defense-related secondary metabolites in acclimation of Artemisia annua L. against short-term UV-B radiation. Planta, 420, 611-627. https://doi.org/10.1007/s00425-014-2114-2

Pandey, V., \& Patra, D. D. (2015). Crop productivity, aroma profile and antioxidant activity in Pelargonium graveolens L' Her. under integrated supply of various organic and chemical fertilizers. Industrial crops and products, 67, 257-263. https://doi.org/10.1016/j.indcrop.2015.01.042

Pereira, G. J. G., Molina, S. M. G., Lea, P. J., Azevedo, R. A. (2002). Activity of antioxidant enzymes in response to cadmium in Crotalaria juncea. Plant and Soil, 239, 123-132. https://doi.org/10.1023/A:1014951524286

Rai, R., Meena, R. P., Smita, S. S., Shukla, A., Kumar Rai, S., Pandey-Rai, S. (2011). UV-B and UV-C pre-treatments induce physiological changes and artemisinin biosynthesis in Artemisia annua L.-An antimalarial plant. Journal of photochemistry and photobiology B: Biology, 105, 216-225. https:// doi.org/10.1016/j.jphotobiol.2011.09.004

Rajendiran, K., Vidya, S., Gowsalya, L., Thiruvarasan, K. (2015). Impact of supplementary UV-B radiation on the morphology, growth and yield of Vigna mungo L. Hepper var. ADT3. International journal of food, agriculture and veterinary science, 5 (2), 104-112.

Salma, H. M. H., Watban, A., Al-fughom, A. T. (2011). Effect of ultraviolet radiation on chlorophyll, carotenoid, protein and proline contents of some annual desert plants. Saudi journal of biological sciences, 18, 79-86. https://doi. org/10.1016/j.sjbs.2010.10.002

Singh, S., Agrawal, S. B., Agrawal, A. (2015). Responses of pea plants to elevated UV-B radiation at varying nutrient levels: N-metabolism, carbohydrate pool, total phenolics and yield. Functional Plant Biology, 42 (11), 1045-1056. https:// doi.org/10.1071/FP15003

Song, J., Smart, R.,Wang, H., Dambergs, B., Sparrow, A., Qian, M. C. (2015). Effect of grape bunch Is sunlight exposure and UV radiation on phenolics and volatile oil composition of Vitis vinifera L. cv pinot noir wine. Food chemistry, 173, 424-431. https://doi.org/10.1016/j.foodchem.2014.09.150 
Takshak, S. S., \& Agrwal, S. B. (2015). Defence strategies adopted by the medicinal plant Coleus Forskohlii against supplemental ultraviolet-B radiation: augmentation of secondary metabolites and antioxidants. Plant Physiology and Biochemistry, 97, 124-138. https://doi.org/10.1016/j. plaphy.2015.09.018

Teramura, A. H. (1983). Effects of UV-B Radiation on the Growth and Yield of Crop Plant. Journal of Plant Physiology, $l$ (58), 415-427. https://doi.org/10.1111/j.1399-3054.1983. tb04203.x

Tossi, V., Lamattina, L., Cassia, R. (2009). An increase in the concentration of abscisic acid is critical for nitric oxide-mediated plant adaptive responses to UV-B radiation. The new phytologist, 181, 871-879. https://doi.org/10.1111/j.14698137.2008.02722.x

Valkama, E., Kivimaenpaa, M., Hartikainen, H., Wulff, A. (2003). The combined effects of enhanced UV-B radiation and selenium on growth, chlorophyll fluorescence and ul- trastructure in strawberry (Fragaria ananassa) and barley (Hordeum vulgare) treated in the field. Agricultural and forest meteorology, 120, 267-278. https://doi.org/10.1016/j. agrformet.2003.08.021

Xu, C., Naratajan, S., Salivan, J. H. (2008). Impact of solar UV-B radiation on the antioxidant defense system in soybean lines differing in flavonoid contents. Environmental and experimental botany, 63, 39-48. https://doi.org/10.1016/j. envexpbot.2007.10.029

Yannarelli, G. G., Gallego, S. M., Tomaro, M. L. (2006). Effect of UV-B radiation on the activity and isoforms of enzymes with peroxidase activity in sunflower cotyledons. Environmental and Experimental Botany, 56, 174-181. https://doi. org/10.1016/j.envexpbot.2005.01.015

Zuk-Golaszewska, K., Upadhyaya, M. K., Golaszewski, J. (2003). The effect of UV-B radiation on plant growth and development. Plant Soil and Environment, 49 (3), 135- 140. https://doi.org/10.17221/4103-PSE 